\title{
Family Member
}

National Cancer Institute

\section{Source}

National Cancer Institute. Family Member. NCI Thesaurus. Code C41256.

Any of the individuals who are descended from a common progenitor, related by

marriage or other legal tie, or by a feeling of closeness. 